\title{
Temporal Trend in Production Subcontracting in Nigeria
}

\author{
Dickson 'Dare Ajayi' \\ Department of Geography, University of lbadan, Nigeria
}

\begin{abstract}
Absract
This paper examines the temporal trend, that is, the growth in production subcontracting over the years in Nigeria. The relevant concepts are production subcontracting and diffusion of innovation. Data were collected from the sixty-eight contracting firms among 15 industrial estates/areas in the Lagos region. This paper shows that the growth in the number of contractors/subcontractors, which was gradual at the initial stage, became more rapid thereafter. The results of the regression/correlation analyses carried out, using the year as the dependent variable and the number of contractors/subcontractors as the independent variable are significant at 0.0001 per.cent level at both the aggregate level and the level of the Lagos region. The study shows that if encouraged, production subcontracting could be used to enhance the industrial development of Nigeria.
\end{abstract}

\section{Introduction}

Two contrasting viewpoints are expressed in the literature about the temporal trend of production subcontracting. On the one hand, Holmes (1986) for instance, remarks that although some subcontracting relationships do remain stable over relatively long periods of time, it is probably more correct to view such relationships as being more fluid and dynamic. This is because the level of subcontracting will ebb and flow with the rhythm of business cycles. In discussing subcontracting resulting from the need to segment labour in order to re-impose market discipline on wages, .Scott (1983: p. 244), notes that "a strong overall hypothesis that emerges is that subcontracting tends to decrease in times of economic improvement, when manufacturers can absorb some degree of internal wage driit, but that it increases again as economic conditions deteriorate and strong cost cutting measures become imperative". In another vein, Friedman (1977), indicates the reverse pattern, with subcontracting increasing during boom periods and declining during downturns in the economy.

Beyond these relatively short-run cyclical variations in the level of subcontracting, Nelson (1975), Clawson (1980), and Littler (1982) show that there are no qualitative shifts in the scale and nature of subcontracting 
associated with shifts from one phase of capitalist accumulation to another. Holmes (1986), however, argues that this assumption "is highly speculative and that it needs much more detailed empirical investigation". This paper, therefore, examines the temporal trend in production subcontracting in Nigeria, using the Lagos region as a case study. The hypothesis tested is that the growth over time in the adoption of production subcontracting as an industrial production technique in Nigeria has been insignificant. Given the present low level of industrial development in Nigeria, there is a sense in which the growth in the adoption of production subcontracting as an industrial production technique can be expected to be insignificant. This is because the diffusion of innovation theory, that is, Hagerstrand $(1952,1953)$ model. of innovation diffusion process shows that the acceptance of an innovation is rather slow at the initial stage.

The study area is the Lagos region. However, given the fact that the main focus of the study is subcontracting relationships between the Lagos region and the rest of the country, there is a sense in which the whole country could be regarded as a subsidiary study area. Therefore, this section discusses various aspects of the industrial geography not only of the Lagos region but also of Nigeria as a whole. The Lagos region, located along the south west of Nigeria, is situated approximately between latitudes $6^{\circ} 27^{1}$ and $6^{\circ} 37^{1}$ North of the equator and longitudes $3^{\circ} 15^{1}$ and $4^{\circ} 47^{1}$ East of the Greenwich Meridian (see Fig. 1). The Lagos region, with an area of about $1,088 \mathrm{~km}^{2}$, covers about 32 per cent of the land area of Lagos State. About 20 per cent of these areas are made up of lagoons and mangrove swamps.

The Lagos region, apart from being the industrial nerve centre, is also the leading centre of commerce in Nigeria. Some 60 to 70 per cent of all commercial transactions in Nigeria are carried out or finalised in the Lagos region. About 70 per cent of the total values of industrial investments in Nigeria are in the Lagos region. Over 65 per cent of the country's industrial employments are concentrated in this region, leaving the remaining 35 per cent to other parts of the country. It is, in part, the recognition of the marked concentration of industries in the Lagos region that motivated its choice as the study area. The implication is that the Lagos region, more than any other part of the country, is likely to have strong links with the other parts of the country.

\section{Conceptual Framework}

Production subcontracting is a very difficult term, which has been used in a variety of ways by a number of authors. Production subcontracting is the arrangement of production process wherein firms externalise their manufacturing activities to other independent firms. The contractor provides the orders and the subcontractor furnishes the work or services for the processing of materials or the production of parts, components, sub- 


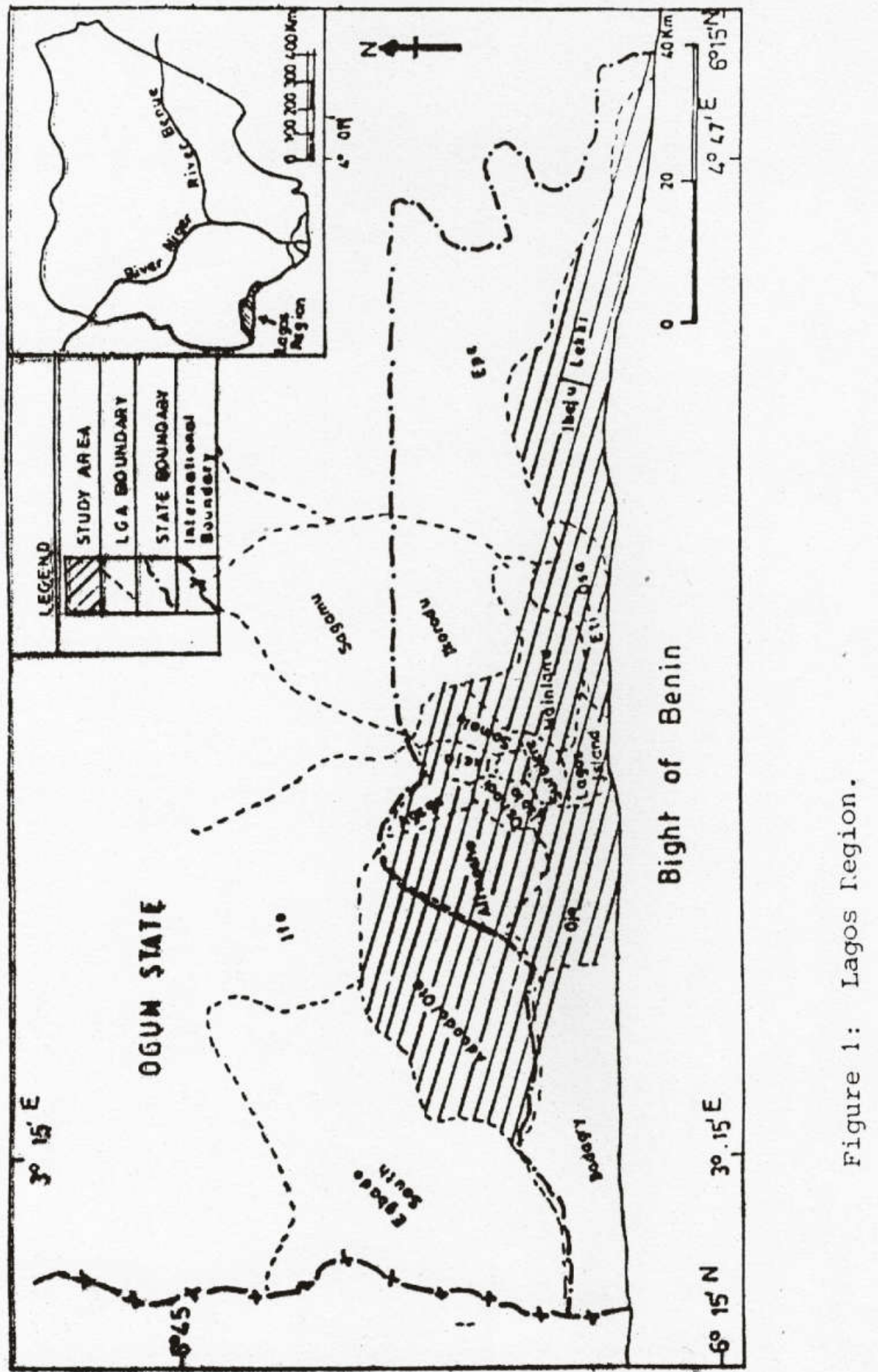


assembly or assembly of products according to the production specifications and the marketing arrangements of the contractor (UNIDO. 1974; Leung, 1993). Production subcontracting is thus a form of industrial linkage. Production subcontracting is classified based on several criteria (see Sharpston, 1975; Taylor and Thrift, 1975; Chaillou, 1977; Watanable, 1971,1972.1980; Leung. 1993; Lawson. 1992; Leung, 1993; Ajayi, 2000; 2001; forthcoming).

Subcontracting here is conceptualised as a diffusion process. Diffusion of innovation refers to the spread of a phenomenon. In this case, it is the spread of an innovation (production subcontracting, an industrial production technique) over space and through time (Gregory, 1994). This suggests that the diffusion of an innovation takes two dimensions. These are spatial diffusion and temporal diffusion. Spatial diffusion is the process by which innovation spreads over space, while temporal diffusion means the spread of innovation over time. It is the diffusion over time that is of interest here. The adoption of subcontracting could be conceptualised as a temporal diffusion process.

Diffusion process has received considerable attention in geographical studies (see, for example, Bowman, 1931; Joerg, 1932; Walter. 1980); in Sociology (Edmunson, 1961; Rogers, 1962) and in Epidemiology (Tinlme, 1992; Gilg, 1973). Hagerstrand's $(1952,1953)$ works form the basis for most geographical studies on the diffusion process. "The acceptance of an innovation is rather slow at the initial stage. This is followed by a rapid build-up as the innovation takes off. Ultimately, there is a levelling out as saturation of the susceptible population is approached". (Hagget et ai, 1977: 238). Thus, the temporal trend of the diffusion of an innovation usually approximates a logistic curve, that is, an S-shaped curve. Innovation diffusion process shows that the acceptance of an innovation is rather slow at the initial stage. A typical S-shaped logistic curve shows clearly the stages of diffusion process. The logistic curve is widely applied (see, for instance, Griliches, 1957; Cassetti and Semple, 1969; Brown and Cox, 1971; Cliff and Ord. 1975; Haming. 1983).

\section{Data Collection Procedure}

Both primary and secondary data were required for this study. While primary data were collected from contracting firms, secondary data were collected from published sources. Since no publication on the location and operation of production subcontracting activities in the country is available, information on these had to be collected from relevant firms. The collection of data from the primary source was done in two different stages. These are the reconnaissance survey and questionnaire administration. - The reconnaissance survey covered all the firms hi the fifteen industrial estates/areas and outlying districts in the Lagos region. In each of the 
industrial estates/areas, all the industrial establishments were visited to determine whether or not they are involved in production subcontracting. The purpose of visiting all firms in each estate and other industrial centres was to ensure that none of the industrial establishments was left uncovered during the survey. The visit entailed personal interview with the industrialists or designated officers (see Ajayi, 1998, for greater details).

The result of the reconnaissance survey indicates that $68(10.7 \%)$ of all the operating firms in the Lagos region are involved in production subcontracting. All the sixty-eight contracting firms identified during the reconnaissance survey were covered in the questionnaire administration carried out from January to August 1996. The relevant aspects of the questionnaire sought information on such issues as the industry group (line of activity); the number and years the contracting relationships have been established. This is necessary so as to be able to establish the number of firms establishing the subcontracting relationships in each of the years. All the contracting firms satisfactorily completed the questionnaire by the end of the fieldwork.

The Industrial Directory of Nigeria (1993 edition)-, published by the Manufacturers' Association of Nigeria (MAN), served as the basic source of secondary data. The 1993 edition was the most recent and up-to-date at the beginning of the fieldwork for the study. The Directory contains a list of manufacturing establishments employing at least 10 workers. Information pertaining to the name, location, and addresses of firms were obtained from this source to determine the location of the contracting firms. Information was collected from other published sources to supplement information provided by the MAN industrial directory.

\section{Results and Discussion}

The issue of interest here is the growth in the number of adopters of production subcontracting as an industrial production technique over the years. Figure 2 shows that production subcontracting as a production technique was first adopted in 1960. On the average, between 1960 and 1994, the number of adopters yearly was two, with a mode of one. The number of adopters varied between zero in some years and 5 in 1986 and 1991. The number of contracting firms (adopters) which was only 1 in I960, increased to 4 by 1964, 7 by 1969, and 16 by 1974. The number further increased to 33 by 1979 , 43 by 1984,57 by 1989, and 68 by 1994. It is obvious from the graph that the growth in the number of adopters was gradual between 1960 and 1969 and became much more rapid thereafter. A close look at the figure shows that the growth in the trend of production subcontracting reflects the early and middle stages of the S-shaped logistic curve of Hagerstrand's $(1952,1953)$ works on the temporal diffusion of innovation. 


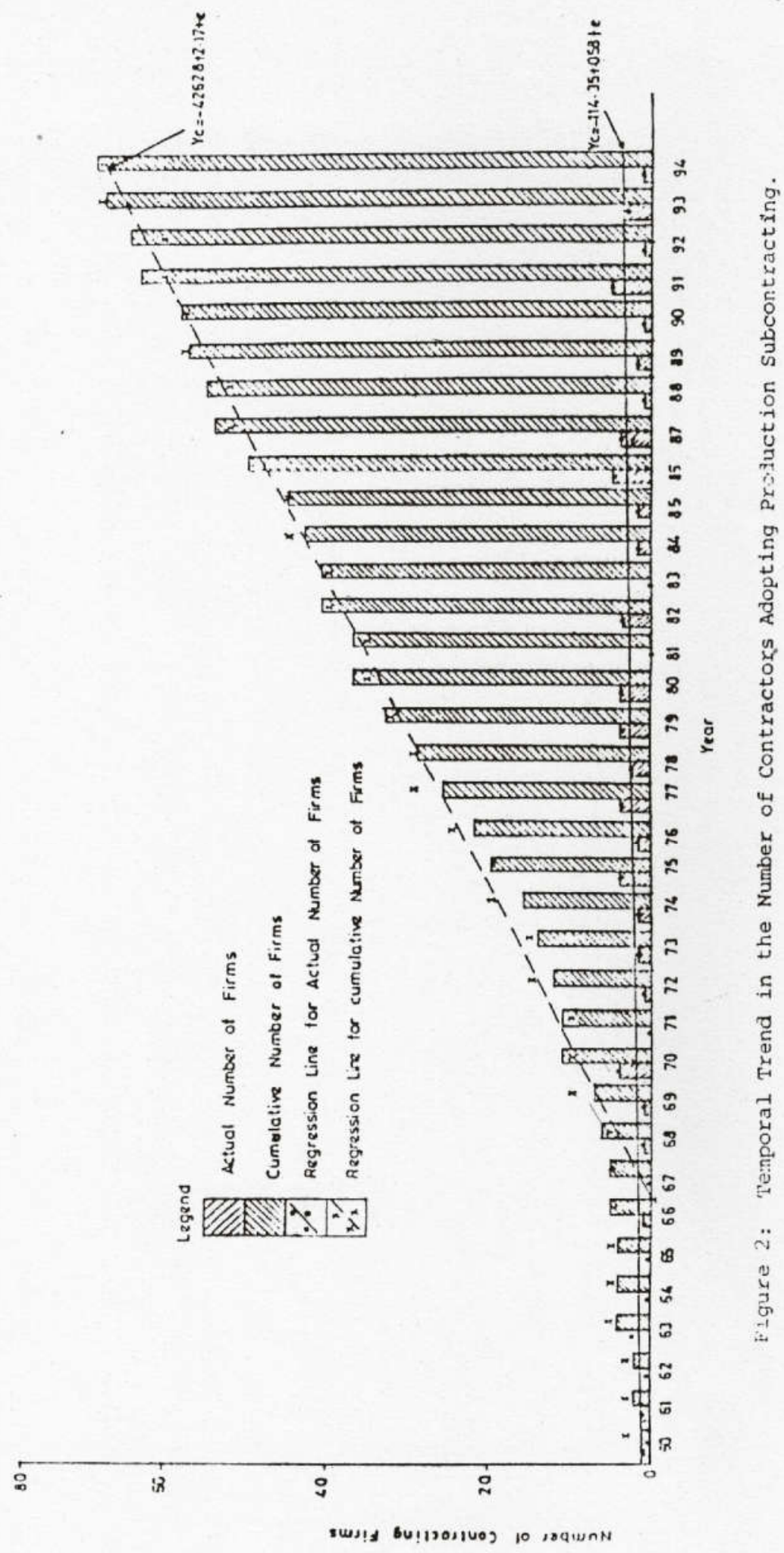



Tatsle 1: Growt h in the Number of Production Subeontractirr,
1960-1994.

\begin{tabular}{|c|c|c|c|c|c|c|}
\hline \multirow{2}{*}{ T'uar } & \multicolumn{2}{|c|}{$\Lambda_{\text {ggregate }}$} & \multicolumn{4}{|c|}{ Lagos Region } \\
\hline & $\begin{array}{l}\text { Actual No. } \\
\text { of Subcontra- } \\
\text { ctors }\end{array}$ & $\begin{array}{l}\text { Cum. No. of } \\
\text { Subcontra- } \\
\text { ctors }\end{array}$ & $\begin{array}{l}\text { Actual No. } \\
\text { of Sub- } \\
\text { contractors }\end{array}$ & $\begin{array}{l}\% \text { of Actual } \\
\text { Aggregatc No } \\
\text { of Sub- } \\
\text { contractors }\end{array}$ & $\begin{array}{l}\text { Cum. No. of } \\
\text { Suhcontr- } \\
\text { actors }\end{array}$ & $\begin{array}{l}\text { \% of Actual } \\
\text { A plprepate No } \\
\text { of Sub- } \\
\text { contractors }\end{array}$ \\
\hline A & B & C & D & $\mathrm{E}$ & $\mathrm{T}$ & G \\
\hline 1960 & 0 & 0 & 0 & 0.0 & 0 & 0 \\
\hline 1961 & 0 & 0 & 0 & 0.0 & 0 & 0 \\
\hline 1962 & 0 & 0 & 0 & 0.0 & 0 & 0 \\
\hline 1963 & 2 & 2 & 2 & 100.0 & 2 & 100.0 \\
\hline 1964. & 0 & 2 & 0 & 0.0 & 2 & 100.0 \\
\hline 1965 & 0 & 2 & 0 & 0.0 & 2 & 100.0 \\
\hline 1966 & 1 & 3 & 0 & 0.0 & 2 & 66.7 \\
\hline 1967 & 0 & 3 & 0 & 0.0 & 2 & 66.7 \\
\hline 1968 & 1 & 4 & 1 & 100.0 & 3 & 75.0 \\
\hline 1969 & 0 & 4 & 0 & 0.0 & 3 & 75.0 \\
\hline 1970 & 2 & 6 & 1 & 50.0 & 4 & 66.7 \\
\hline 1971 & 0 & 6 & 0 & 0.0 & 4 & 66.7 \\
\hline 1972 & 2 & 8 & 1 & 50.0 & 5. & 62.5 \\
\hline 1973 & 1 & 9. & 1 & 100.0 & 6 & 66.7 \\
\hline 1974 & 6 & 15 & 6 & 100.0 & 12 & 80.0 \\
\hline 1975 & 3 & 18 & 2 & 66.7 & 14 & 77.8 \\
\hline 1976 & 1 & 19 & 0 & 0.0 & 14 & 73.7 \\
\hline 1977 & 6 & 23 & 5 & 83.3 & 19 & 76.0 \\
\hline 1978 & 4 & 29 & 3 & 75.0 & 22 & 75.9 \\
\hline 1979 & 6 & 35 & 6 & 100.0 & 28 & 80.0 \\
\hline 1980 & 6 & 41 & 4 & 66.7 & 32 & 78.0 \\
\hline 1981 & 4 & 45 & 4 & 100.0 & 36 & 80.0 \\
\hline 1982 & 6 & 51 & 4 & 66.7 & 40 & 78.4 \\
\hline 1983 & 4 & 55 & 4 & 100.0 & 44 & 80.0 \\
\hline 1984 & 11 & 66 & 9 & 81.8 & 53 & 80.3 \\
\hline 1985 & 9 & 75 & 9 & 100.0 & 62 & 82.7 \\
\hline 1986 & 8 & 83 & 8 & 100.0 & 70 & 84.3 \\
\hline 1987 & 9 & 92 & 9 & 100.0 & 79 & 85.9 \\
\hline 1988 & 10 & 102 & 8 & 80.0 & 87 & 85.3 \\
\hline 1989 & 9 & 111 & 9 & 100.0 & 96 & 86.5 \\
\hline 1990 & 15 & 126 & 13 & 86.7 & 109 & 86.5 \\
\hline 1991 & 11 & 137 & 11 & 100.0 & 120 & 87.6 \\
\hline 1992 & 13 & 150 & 10 & 76.9 & 130 & 86.7 \\
\hline 1993 & 11 & 161 & II & 100.0 & 141 & 87.6 \\
\hline 1994 & 11 & 172 & 7 & 63.6 & 148 & 85.5 \\
\hline
\end{tabular}

Note: Col.D/Col. B $\times 100=$ Col. E; Col.F/Col.C $\times 100=$ Col.G. 
Table 1 shows the growth in the number of subcontractors between 1960 and 1994. Both the actual and cumulative number of subcontractors at the aggregate level and the Lagos region are shown in the Table. In addition, the Table shows the situation in the Lagos region as a percentage of the aggregate situation. There are no records showing the number of subcontractors between 1960 and 1962. This is because the contractors could not provide adequate information on the number of subcontractors engaged during this period. The Table shows that the number of subcontractors engaged varied between zero and 15. On the average, between 1960 and 1994, the number of subcontractors increased by five each year.

The number of subcontractors, which was not more than 2 in any of the years up to 1973, increased to 6 by 1974 and 1979. All of these were found in the Lagos region. By 1984, when the aggregate number of subcontractors increased to 11, Lagos region alone had 9 ( 81.8 per cent) All the 9 subcontractors in 1989 were found in the Lagos region, while by 1994 when the number of subcontractors was 11, 7 (63.6 per cent) were in the Lagos region. The Table further shows that while, the number of subcontractors was 2 in 1964, all were within the Lagos region. The number in the Lagos region increased to 3 ( 75.0 per cent) out of the total number of 4 subcontractors by 1969 . By 1974, when the number of subcontractors was 15 , the share of the Lagos region was 12 ( 80.0 per cent). By 1979, out of the 35 subcontractors, 28 (80.0 per cent) were hi the Lagos region. The share of the Lagos region increased to 53 (80.3 per cent) out of the 66 subcontractors by 1984, 96 (86.5 per cent) out of 111 by 1989 and 142 (85.5 per cent) of the total 172 subcontractors in 1994. It is obvious from the Table that the growth in the number of subcontractors was gradual between 1960 and 1983. There has been a much more rapid increase thereafter.

At the aggregate level, the result of a linear regression/correlation analysis of the trend, for cumulative number of contractors (adopters). Table 2, using the year as dependent variable and number of contractors as independent variable, indicates that $\mathrm{R}$ is 0.98476 , and $\mathrm{R}^{2}$ is 0.96975 . The regression line is indicated in Figure 2. The result is significant at the 0.0001 percent level. The conclusion that may be drawn is that the growth in the adoption of production subcontracting as an industrial production technique in Nigeria is significant. The result of a regression/correlation analysis using the actual number of adopters in each year shows that $\mathrm{R}$ is 0.37925 while $\mathrm{R}^{2}$ is 0.14383 . The level of significance is as low as 0.02 percent.

The result of a linear correlation/regression analysis of the trend for aggregate cumulative number of subcontractors indicates that $\mathrm{R}$ is 0.92152 , and $\mathrm{R}^{2}$ is 0.84920 , while that for the aggregate actual number of subcontractors shows that $\mathrm{R}$ is 0.92143 , and $\mathrm{R}^{2}$ is 0.84904 .,In the Lagos 
region, the result of a linear correlation/regression analysis of the cumulative number of subcontractors indicates that $\mathrm{R}$ is 0.91096 , and $\mathrm{R}^{2}$ is 0.82986 , while that for the actual number of subcontractors for each of the years shows that $R$ is 0.89383 and $R^{2}$ is 0.79893 . These results are significant at 00001 per cent level. The implication is that the trend in the growth of production subcontractors over time at both the aggregate level and the level of Lagos region each is highly significant.

The temporal variation in the adoption of production subcontracting by the industry groups of contractors, Figure 3, shows that between 1960 and 1964, only four industry groups were involved in production subcontracting. These industry groups were (1) food, beverages and tobacco; (2) chemicals and Pharmaceuticals; (3) basic metal, iron and steel and fabricated metal products, and (4) textiles, wearing apparel and leather The pulp, paper and paper products, printing and publishing industry group featured between 1965 and 1969. Other industry groups did not start production subcontracting until the period between 1975 and 1979.

Table 2:-Summary of the Linear Correlation/Regression Analysis for the Cumulative Number of Contractors

$\begin{array}{lllll}\text { Variable } & \text { B } & \begin{array}{l}\text { Standard } \\ \text { Error of } B\end{array} & \text { T } & \begin{array}{l}\text { Level of } \\ \text { Significance }\end{array}\end{array} \quad \mathbf{R}^{2}$

Cumulative

Number of

Contractors

2.170868

0.066739

32.528

$0.0001 \quad 0.98476$

0.96975

$\begin{array}{lllll}\text { Constant } & -4262.835294 & 131.945342 & -32.308 & 0.0001\end{array}$ 
$120-$

100

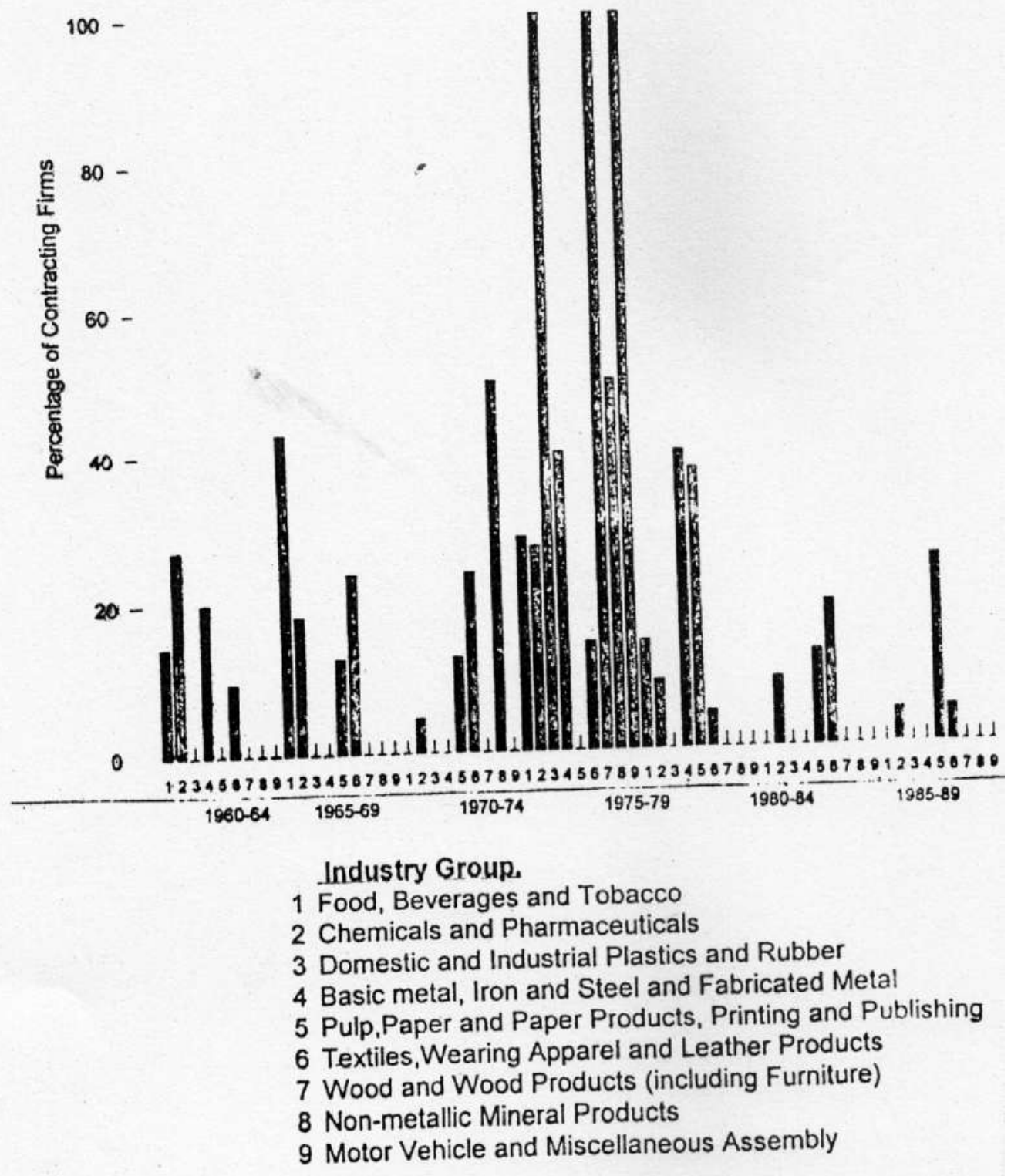

Figure 3. Temporal Trend in the Number of Contractors in each Industry Group. 
Table 1: Growt h in the Number of Production Subcontractors? 1960-1994.

\begin{tabular}{|c|c|c|c|c|c|c|}
\hline \multirow{2}{*}{ Y'ar } & \multicolumn{2}{|c|}{$\Lambda_{\text {bgregate }}$} & \multicolumn{4}{|c|}{ Lagos Region } \\
\hline & $\begin{array}{l}\text { Actual No. } \\
\text { of Subcontra- } \\
\text { cturs }\end{array}$ & $\begin{array}{l}\text { Cuni. No. of } \\
\text { Sulicontra- } \\
\text { clors }\end{array}$ & $\begin{array}{l}\text { Actual No. } \\
\text { of Sub- } \\
\text { contractors }\end{array}$ & $\begin{array}{l}\% \text { of Actual } \\
\text { Aggregate No } \\
\text { of Sub- } \\
\text { contractors }\end{array}$ & $\begin{array}{l}\text { Cunn. No, of } \\
\text { Subcontr- } \\
\text { actors }\end{array}$ & $\begin{array}{l}\text { \% of Actual } \\
\text { Aggregate No } \\
\text { of Sub- } \\
\text { contractors }\end{array}$ \\
\hline A & B & C & $D$ & $E$ & $\mathrm{~T}$ & $G$ \\
\hline 1960 & 0 & 0 & 0 & 0.0 & 0 & 0 \\
\hline 1961 & 0 & 0 & 0 & 0.0 & 0 & 0 \\
\hline 1962 & 0 & 0 & 0 & 0.0 & 0 & 0 \\
\hline 1963 & 2 & 2 & 2 & 100.0 & 2 & 100.0 \\
\hline 1964 & 0 & 2 & 0 & 0.0 & 2 & 100.0 \\
\hline 1965 & 0 & 2 & 0 & 0.0 & 2 & 100.0 \\
\hline 1966 & 1 & 3 & 0 & 0.0 & 2 & 66.7 \\
\hline 1967 & 0 & 3 & 0 & 0.0 & 2 & 66.7 \\
\hline 1968 & 1 & 4 & 1 & 100.0 & 3 & 750 \\
\hline 1969 & 0 & 4 & 0 & 0.0 & 3 & 75.0 \\
\hline 1970 & 2 & 6 & 1 & 50.0 & 4 & 66.7 \\
\hline 1971 & 0 & 6 & 0 & 0.0 & 4 & 66.7 \\
\hline 1972 & 2 & 8 & 1 & 50.0 & 5 & 62.5 \\
\hline 1973 & 1 & 9 & 1 & 100.0 & 6 & 66.7 \\
\hline 1974 & 6 & 15 & 6 & 100.0 & 12 & 80.0 \\
\hline 1975 & 3 & 18 & 2 & 66.7 & 14 & 77.8 \\
\hline 1976 & 1 & 19 & 0 & 0.0 & 14 & 73.7 \\
\hline 1977 & 6 & 25 & 5 & 83.3 & 19 & 76.0 \\
\hline 1978 & 4 & 29 & 3 & 750 & 22 & 75.9 \\
\hline 1979 & 6 & 35 & 6 & 100.0 & 28 & 80.0 \\
\hline 1980 & 6 & 41 & 4 & 66.7 & 32 & 78.0 \\
\hline 1981 & 4 & 45 & 4 & 100.0 & 36 & 80.0 \\
\hline 1982 & 6 & 51 & 4 & 66.7 & 40 & 78.4 \\
\hline 1983 & 4 & 55 & 4 & 100.0 & 44 & 80.0 \\
\hline 1984 & 11 & 66 & 9 & 81.8 & 53 & 80.3 \\
\hline 1985 & 9 & 75 & 9 & 100.0 & 62 & 82.7 \\
\hline 1980 & 8 & 83 & 8 & 100.0 & 70 & 84.3 \\
\hline 1987 & 9 & 92 & 9 & 100.0 & 79 & 85.9 \\
\hline 1988 & 10 & 102 & 8 & 80.0 & 87 & 85.3 \\
\hline 1989 & 9 & 111 & 9 & 100.0 & 96 & 86.5 \\
\hline 1990 & 15 & 126 & 13 & 80.7 & 109 & 86.5 \\
\hline 1991 & 11 & 137 & 11 & 100.0 & 120 & 87.6 \\
\hline 1992 & 13 & 150 & 10 & 76.9 & 130 & 86.7 \\
\hline 1993 & 11 & 161 & 11 & 100.0 & 141 & 87.6 \\
\hline 1994 & 11 & 172 & 7 & 63.6 & 148 & 85.5 \\
\hline
\end{tabular}

Note: Col.D/Col. B $\times 100=$ Col. E; Col.F/Col.C $\times 100=$ Col.G. 
Table 3 shows the percentage of subcontractors that adopted subcontracting in each time period. Before 1970, only 1 (1.5 percent) of the subcontractors in chemicals and pharmaceuticals; 2 (7.7 per cent) in pulp, paper and paper products, printing and publishing; and 3 ( 7.1 per cent) in textiles, wearing apparel and leather industry groups were involved in production subcontracting. Two other industry groups, 2 (12.5 per cent) in food, beverages and tobacco; and 1 ( 9.0 per cent) in basic metal, iron and steel and fabricated metal products became involved only in the 1970 to 1974 period. Subcontractors in domestic and industrial plastics and rubber industry group were not involved until the period between 1980 and 1984.

\section{Conclusion}

It is evident from the foregoing analysis that the growth in the adoption of production subcontracting as an industrial production technique in Nigeria, over the years, has been significant. The implication of this growth for policy measures is that, if encouraged, production subcontracting could be used to enhance the industrial development of Nigeria in particular and other developing economies of the world in general. The literature shows, for instance, that in Japan, the promotion of industrial subcontracting in economic development is largely motivated by the participation of small-scaled entrepreneurs. Such motivation could be in either of two forms.

On the one hand is the encouragement of retirees to set up small business units with the motive of producing parts or sub-assembly of products. Such retirees will be more able to bring their experiences, acquired over the years, to bear on part production or sub-assembly of products, based on mutual trust. Such encouragement could be in form of assisting the retirees to set up small business units or providing the required capital or both. On the other hand, the government is involved in setting up, and facilitating collaborative ventures between large and small-scale enterprises, especially in the hinterlands. By so doing, the country's industrial strategy of effecting a more even distribution of industrial activities in all parts of Nigeria can be realised.

No doubt, the development of transport facilities will enhance the operations of subcontractors located in the hinterlands. In addition, the government's initiative at encouraging the local manufacture of industrial products hitherto imported could be enhanced through the encouragement of production subcontractors. The subcontracting of specialised aspects of industrial production could be better explored for the development of indigenous entrepreneurship, and especially the development of the Export Processing Zone (EPZ), It must be stated, however, that industrial production subcontracting is a strategy for mobilising both human and material resources for industrial development. 


\section{References}

I wish to thank Professor Chris Ikporukpo, Department of Geography, University of Ibadan for supervising the work part of which is reported here, and the invaluable comments on the earlier drafts of this article. This research was conducted, in part, with the financial support from the Council for the Development of Social Science Research in Africa (CODESRIA), Dakar, Senegal. That support is appreciated.

Ajayi, D.D. (1998), Spatial Patterns of Production Subcontracting in Nigeria: A Case Study of the Lagos Region. Ph.D. Thesis, Department of Geography, University of Ibadan, Nigeria.

Ajayi, D.D. (2000), "The Determinants of Production Subcontracting in Nigeria", Nigeria Journal of Economics and Social Studies, Vol. 42(1): 95-111.

Ajayi, D.D. (2001), "Nature and Scope of Production Subcontracting in Nigeria", The Indonesian Journal Of Geography, Vol. 32(2): 83-101.

Ajayi, D.D. (forthcoming), "Spatial Pattern of Production Subcontracting in Nigeria", Research for Development Journal - NISER, Ibadan.

Bowman, I. (1931), The Pioneer Fringe, New York.

Brown, L.A and K.R. Cox (1971), "Empirical Regularities in the Diffusion of Innovation", Annals of the Association of American Geographers, 61.

Casetti, E., K.Semple(1969), "Concerning the Testing of Hypotheses", Geographical Analysis, 1:154-9. Chaillou, B. (1977), "Definition et typologie de la sous traitance". Revue Economique, 28(2), pp.262-285. Clawson, D. (1980), Bureaucracy Transformation of U.S Industry Review Press.

Cliff, A.D. and J.K. Ord (1975), "Space-time Modelling with an Application to Regional Forecasting”, Institute of British Geographers, Publications: 64:119-28.

Edmundson, M.S. (1961), "Neolithic Diffusion Rates", Current Anthropology, 2:71-102. Friedman, A.L. (1977), Industry and Labour: Class Struggle at Work and Monopoly Capitalism. London: Macmillan.

Gilg, A.W. (1973),"A Study in Agricultural Disease Diffusion", Institute of British Geographers Publications, 59:77-97.

Gregory, D. (1994), "Diffusion”. In: Johnston, R.J., D. Gregory and D.M. Smith, (eds), The Dictionary of Human Geography, 3rd edition, 132-135.

Griliches, Z. (1957), "Hybrid Com: An Exploration in the Economics of Technological Change", Econometrica, 25, pp.501-22. and the Labour Process: The 1860-1920, New York: Monthly 
Hagerstrand, T. (1952), "The Propagation of Innovation Waves”, Lund Studies in Geography, B., Human Geography, 4:3-19.

Hagerstrand, T. (1953), Innovation for Loppet Ur. Korologisk Synpunkt.

Hagget, P. et aL (1977), Locational Models. Second Edition.Edward Arnold, Chapter 7:231-258.

Haming, R. (1983), "Spatial and Spatial-Temporal-Integration Models and the Analysis of Patterns of Diffusion", Institute of British Geographers Transactions, 8(2): 158-86.

Holmes,J.(1986), "The Organisational and Locational Structure of Production Subcontracting". In: Scott,A.J. and M.Storper (eds), Production, Work, and Territory: the Geographical Anatomy of Industrial Capitalism. Boston: Allen and Unwin, pp. 80-106,

Joerg, W.L.G. ed. (1932), Pioneer Settlement, N.Y.

Lawson, V.A. (1992), "Industrial Subcontracting and Employment Forms in Latin America: A Framework for Contextual Analysis", Progress in Human Geography, 16, pp. 1-23.

Leung, C.K. (1993), "Personal Contacts, Subcontracting Linkages, and Development in the Hong Kong - Zhujiang Delta Region", Annals of the Association of American Geographers, 83(2), pp. 273.-302.

Nelson, D. (1975), Managers and Workers: Origins of the New Factory System in the United States, 1S80-J920. Madison: University of Wisconsin Press.

Rogers, A. (1962), "Industrial Inertia: A Major Factor in the Location of the Steel Industry in the United States", Geographical Review, 42:56-65.

Scott, A.J. (1983), "Industrial Organization and the Logic of Intra- Metropolitan Location 1: Theoretical Considerations", Economic Geography, 59(3): 233250 .

Sharpston, M. (1975), International Subcontracting. Oxford Economic Paper, 27, pp. 94-135.

Taylor. M. J. and N.J Thrift, (1975), "The Industrial Linkages of Aukland Manufacturers", Proceedings of the International Geographical Union Regional Conference and Eighth Newzealand Geography Conference, pp. 203-17.

Tinline, R. R. (1972), A Simulation Study of the 1967/8 Foot-and-mouth Epizootic in Gre, at Britain University of Bristol. Ph.D. Dissertation.

United Nations Industrial Development Organisation -UNIDO, (1974). Subcontracting for Modernizing Economies. Vienna, UN.

Walter, B (1980),"Time-Space Patterns of Second-Wave Irish Immigration into British Towns". Institute of British Geographers, Transactions, 5(3): 297-317.

Watanable, S. (1971). "Entrepreneurship in Small Enterprises in Japanese Manufacturing", International Labour Review, 102, pp. 531-575. 
Watanable, S. (1972), "International Subcontracting, Employment and Skill Promotion", International Labour Review, 105, pp.425-449.

Watanable, S. (1980), International Subcontracting and Regional Economic Integration in the Asian Countries: The Role of Multinationals". In: Germidis, D. (ed), International Subcontracting, Paris: Organisation for Economic Cooperation and Development, pp. 210-227. 